\title{
Staff Retention in an Information Management Environment
}

\author{
Mrs W Odendaal
}

Faculty of Management Sciences, Vaal University of Technology Private Bag X021, Vanderbijpark 1900, South Africa

Dr Y van Zyl

Faculty of Management Sciences, Vaal University of Technology Private Bag X021, Vanderbijpark 1900, South Africa

E-mail: yolandivz@vut.ac.za

Prof J Surujlal

Faculty of Economic Sciences and Information Technology North-West University, PO Box 1174, Vanderbijlpark 1900, South Africa E-mail: Babs.Surujlal@nwu.ac.za

\section{Doi:10.5901/mjss.2014.v5n13p495}

\begin{abstract}
The retention of valuable employees is one of the most critical issues that human resource managers have faced in the past decade. A plausible reason for this is that talented employees who have competencies that are critical for the survival of an organisation are often difficult to attract and retain because they often attach more importance to their own career paths than to organisational loyalty. More often than not this results in voluntary turnover. Organisations are now operating more strategically and realise that survival depends on, retaining existing talented people who have the essential knowledge, expertise and competencies to perform the tasks in an organisation. The need to create an attractive work environment to current and future job applicants is also recognised. Therefore, an understanding of the way individuals conduct themselves is much needed. The purpose of this study was to examine staff retention in an information management environment. A quantitative research approach using a questionnaire to collect data from 50 employees working in an information management environment was adopted. The questionnaire was used to measure employee job satisfaction and to identify job satisfaction factors. The findings revealed that communication, good working conditions, job security, opportunities for learning and growth, and recognition were perceived, in this order, as being the most important job satisfaction factors. It was evident that employee expectations for job satisfaction were not met in the areas of recognition and good supervision/leadership. Employee expectations for job satisfaction were only partially met in the areas of communication, opportunities for learning and growth, promotional opportunities and compensation.
\end{abstract}

Keywords: Retention, motivation, job satisfaction, information management

\section{Introduction}

Employees constitute the primary resource of any organisation. It is difficult to imagine any organisation prospering and surviving without this vital resource in the current competitive business climate. Hence, globally the retention of valuable employees is one of the most critical issues confronting human resources managers (Mayfield \& Mayfield, 2008). Competent and talented employees who are critical for the survival of an organisation are difficult to retain because they often attach more importance to their own career path than to organisational loyalty, which, in turn, can result in voluntary turnover (De Vos\&Meganck, 2009). Organisational flexibility, accompanied by increasing uncertainty about job security, has made a job for life a thing of the past in many organisations (Arnold \& Feldman, 1988) with many being less willing to offer lifelong career progression.Careers have, therefore, become increasingly boundary-less and self-managed owing to an environment that no longer readily offers long-term employment (Van Dam, 2008).

Turnover comes about when there is a permanent withdrawal of an employee from the employing organisation (George \& Jones, 2005). Employers and employees experience turnover as a costly process because for the employer there is high replacement and organisational cost, whilst the employees experiences monetary and psychological costs (Huang, Lin \& Chuang, 2006). High turnover in an organisation has several implications. Among these are increased 
recruitment, selection and training costs. In addition the efficient running of the organisation is disrupted when knowledgeable and efficient employees leave the organisation (Robbins, Odendaal\&Roodt, 2004). Mayfield and Mayfield (2008) found that when considering the price of reassigned work load, lost organisational memory, and successor recruitment and training, the average turnover cost can range beyond 1.5 times an employee's annual salary. The intangible cost, according toGostick and Elton (2007),is a decimated workforcewhich may influence the remaining workers to follow their departing colleagues. Furthermore, it disrupts the normal flow of work which may have serious consequences for productivity in the organisation. It is therefore important that additional human resource expenses be significantly reduced by implementing effective employee retention strategies (Taylor, Murphy \& Price, 2006). It must, however, be noted that organisations can also benefit from turnover in certain situations, such as when poor performers leave and good performers stay or when new recruits result in the introduction of new ideas and approaches (George \& Jones, 2005). Mobley's model of the turnover process (George \& Jones, 2005) suggests that the turnover process is influenced by a lack of job satisfaction; implying that employees who are satisfied with their jobs may never even think about quitting, while those who are dissatisfied will, as a result of this dissatisfaction, start to think about quitting.

Research has shown that the issue of job satisfaction has been considered as a key precursor of voluntary turnover (Park \& Kim, 2009). Job satisfaction is defined by Nelson and Quick (2006) as a pleasurable or positive emotional state that is the result of the appraisal of one's job or job experience. O'Malley (2000) argues that employees who enjoy their jobs work harder and stay longer with their employers than those who do not. In contrast, if the job satisfaction level is low, employees will develop a behavioural intention to quit (Luna-Arocas\& Camps, 2008). Satisfied workers are likely to want to reciprocate their positive experiences by giving something back to the organisation (Nelson \& Quick, 2006). In addition, job satisfaction has the potential to affect a wide range of behaviours in organisations thereby contributing to higher levels of employee well-being (George \& Jones, 2005). Glen (2006:37) points out that, factors such as key skills retention, employee engagement and, to a lesser extent, employee motivation and attendance, have a direct impact on organisational costs, productivity and business performance.

Employees who are motivated exert greater effort to perform than those who are not motivated (Fox, 2006). While employees are motivated for their own reasons (Clark, 2009), George and Jones (2005) argue that the strength of employees' motives, which are directed towards goals (often called incentives), influences their motivation.Employees join organisations so that certain needs of theirs are met. As long as those needs are satisfied in relation to the effort they apply, they will remain effective members of an organisation (Amos, Ristow\&Ristow, 2004). It could be therefore be argued that at work employees can often be successfully motivated if they are provided with an environment in which appropriate goals are available for the satisfaction of their needs (Fox, 2006). Even so, consideration must be given to the fact that employees have different needs and it is therefore necessary to spend time with them to understand these needs (Robbins et al., 2004).

\section{Problem statement}

Managers face two significant ongoing organisational issues, namely eliciting the commitment of employees and staff retention (Chew \& Chan, 2008). If employees are committed to an organisation, they are less likely to leave or be absent and may also display other behaviours which are valuable to the organisation (Maurer \&Lippstreu, 2008). Kaye and Jordan-Evans (2005) indicate that managers should stop guessing what it is that keeps their 'stars' home and happy they should not assume that all employees desire the same thing, such as, for example pay or promotion. It is therefore important that in a highly competitive environment managers are aware of what it is that attracts employees to the organisation and what is needed to retain them.

Kaye and Jordan-Evans (2005) believe that given the fact that outstanding employees are an organisation's most critical asset which gives an organisation a competitive advantage, organisations face a huge challenge to establish a reservoir of talent needed to help an organisation achieve its objectives. The organisation's ability to attract and retain the best people will determine the depth, breadth and quality of this reservoir of talent (O'Malley, 2000).

It is evident that a crucial factor in the survival and success of any organisation is the retention of those talented employees who have the requisite knowledge, expertise and competencies. In order to manage retention, human resources managers need to understand why people behave as they do. Fox (2006) suggests that this includes not only the ability to understand and predict behaviour but also the ability to control, direct and change behaviour. It is therefore necessary to understand what encourages people to put in the required and sometimes added effort to complete their tasks effectively. Furthermore, in order to retain such employees as a knowledge source, it is imperative to know what factors motivate them. 


\section{Purpose of study}

This study focuses on staff retention in an information management department in a petrochemical organisation.

\section{Methodology}

A quantitative research strategy was followed. The purpose of quantitative research may also be described as the evaluation of objective data that consists of numbers, where the aim is not to deal directly with everyday life but rather with an abstraction of reality (Welman, Kruger \& Mitchell, 2005:8).

\subsection{Sample}

The target population for this research study involved individuals working in the information management department of an organisation in South Africa. Information management relates to management activities concerning information which includes the creation, capture, deployment, use, sharing, development and evaluation of information. This comprises several activities such as information security, backup and recovery, data quality and sharing. More organisations are thinking and operating strategically and their very survival depends on information. In order to compete and survive in the current marketplace, most organisations recognise that information and the systems supporting that information are important business assets for establishing and leveraging information-based resources and competence.

This information management (IM) environment consists of two subdivisions, namely information management business partnering and unique applications and information management - electronics and communication. This structure is illustrated in Figure 1.

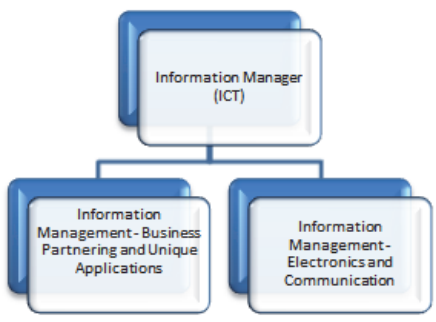

Figure 1: Information management structure

From the illustration in Figure 1 it can be seen that the subdivisions report to a central information manager. It must be noted that for this study the population included employees as well as managers. The population for this study consisted of 50 employees; therefore, the entire population formed part of the sample. The sample size was thus set at $n=50$. As the entire population formed part of the sample, this study constituted a census (De Vos, Strydom, Fouche\& Delport, 2005:217).

\subsection{Procedures}

Data was collected by means of a survey, using a questionnaire. For the purpose of this study, the relevant questionnaire was distributed to all persons employed at the information management department. The most important purpose of the questionnaire was to test the information gathered from the literature study, as well as to investigate the perceptions that employees might have of employee job satisfaction levels within the information management department. The questionnaires were distributed to 50 individuals, of which 41 completed questionnaires were returned, representing a response rate of 82 percent.

\subsection{Ethical issues}

Permission to carry out the research project was gained from the organisation. A letter accompanied the questionnaire, with the aim of informing the respondents about the purpose of this study and to provide them with the assurance that all 
information obtained through the questionnaire would be treated as confidential and that the results would only be used for research purposes.

\subsection{Measuring instrument}

The questionnaire consisted of three sections: Section A - Personal and biographical information; Section B - Job satisfaction scale; and Section C - Job satisfaction factors.

Section $A$, the personal and biographical information section, covered the more general questions of the study. It consisted of questions regarding gender, age, department (ICT or IM), pipeline layer (managing others or not), years in current position and years with the organisation.

Section B, the job satisfaction scale, consisted of 26 statements relating to the job satisfaction factors that were identified through the literature study. The aim of these questions were to evaluate how employees perceive their level of job satisfaction in the following areas: working conditions, stimulating tasks, responsibility and accountability for results, opportunities for learning and growth, promotional opportunities, compensation/pay, recognition, co-workers, communication, supervision/leadership and job security.

The purpose of Section $\mathrm{C}$ of the questionnaire was to establish the importance of each of the job satisfaction factors, which were identified during the literature study.

Clear instructions were provided to the respondents on how to complete each section of the questionnaire. The questionnaire consisted only of closed-ended questions. In Section A, the respondents were provided with corresponding multi-choice answers to each question from which they only had to select their appropriate option. Sections $B$ and $C$ of the questionnaire comprised statements anchored on a five-point Likert-type scale. The five-point scale allowed for a possibility of a neutral answer. In Section B, ' 1 ' was associated with being rated as 'Strongly Disagree' and ' 5 ' as being 'Strongly Agree'. These ratings continued into Section $C$, the only change being that on the scale of ' 1 ' to ' 5 ' the ' 1 ' represents 'Not Important' and '5' 'Very Important'.

\subsection{Data analyses}

Data were analysed using descriptive statistics. Tabulation was used to make comparisons in the demographics of the data and was also used as a basis for presenting the data graphically. The Statistical Package for Social Sciences (SPSS - Version18 for Windows) was used to analyse the data. Descriptives and frequencies were used to report on the data.

\section{Results and Discussion}

The study population for this research comprised 50 individuals. The participants included employees in different subdepartments of the information management department, as well as managers. Of the questionnaires which were administered forty one completed questionnaires $(n=41 ; 82 \%)$ were received. 


\subsection{Demographics}

The demographic information of the participants is provided in Table 1.

Table 1: Demographics

\begin{tabular}{|c|c|c|c|}
\hline Item & Category & Frequency & Percentage \\
\hline \multirow[t]{2}{*}{ Gender } & Male & 27 & $69.2 \%$ \\
\hline & Female & 12 & $30.8 \%$ \\
\hline \multirow[t]{4}{*}{ Age of employees } & $18-30$ years & 6 & $15.4 \%$ \\
\hline & $31-40$ years & 19 & $48.7 \%$ \\
\hline & $41-50$ years & 8 & $20.5 \%$ \\
\hline & Older than 50years & 6 & $15.4 \%$ \\
\hline \multirow[t]{2}{*}{ ICT department } & Information Management & 21 & $55.3 \%$ \\
\hline & Electronics and communication & 17 & $44.7 \%$ \\
\hline \multirow[t]{2}{*}{ Pipeline layer } & Managing self & 31 & $77.5 \%$ \\
\hline & Managing others & 9 & $22.5 \%$ \\
\hline \multirow[t]{5}{*}{ Years employed in current position } & $1-3$ years & 14 & $35.9 \%$ \\
\hline & $4-7$ years & 17 & $43.6 \%$ \\
\hline & $8-11$ years & 3 & $7.7 \%$ \\
\hline & $12-15$ years & 2 & $5.1 \%$ \\
\hline & More than 15 years & 3 & $7.7 \%$ \\
\hline \multirow[t]{5}{*}{ Years employed within the organisation } & $1-3$ years & 5 & $12.8 \%$ \\
\hline & $4-7$ years & 8 & $20.5 \%$ \\
\hline & $8-11$ years & 4 & $10.3 \%$ \\
\hline & $12-15$ years & 11 & $28.2 \%$ \\
\hline & More than 15 years & 11 & $28.2 \%$ \\
\hline
\end{tabular}

The majority of the respondents were male (69.2\%). Most of the respondents (48.70\%) were between 31 and 40 years of age, followed by the 41 to 50 year age group, which accounted for 20.5 percent of the respondents. The majority of the respondents worked in the information management department $(55.30 \%)$. The results shows that 22.5 percent of the employees have people reporting to them, which indicate that they are involved in management. From the responses it can be seen that the majority of employees $(43.6 \%)$ were employed in their current position for between four and seven years. The majority of employees had been with the organisation for between 12-15 years (28.2\%) and more than 15 years $(28.2 \%)$. This is followed by a group of 20.5 percent that had been with the organisation for between four and seven years.

\subsection{Perceptions of job satisfaction}

Employees' perceptions of job satisfaction was evaluated in the following areas: working conditions, stimulating tasks, responsibility and accountability for results, opportunities for learning and growth, promotional opportunities, compensation/pay, recognition, co-workers, communication, supervision/leadership and job security.

\subsubsection{Working conditions}

As shown in Figure 2, it can be observed that the majority of employees indicated that they were satisfied with their working conditions with the majority of the responses falling in the "agreed" and "strongly agreed" categories. This indicates that employees are happy to work at their organisation and are satisfied with their working conditions. 


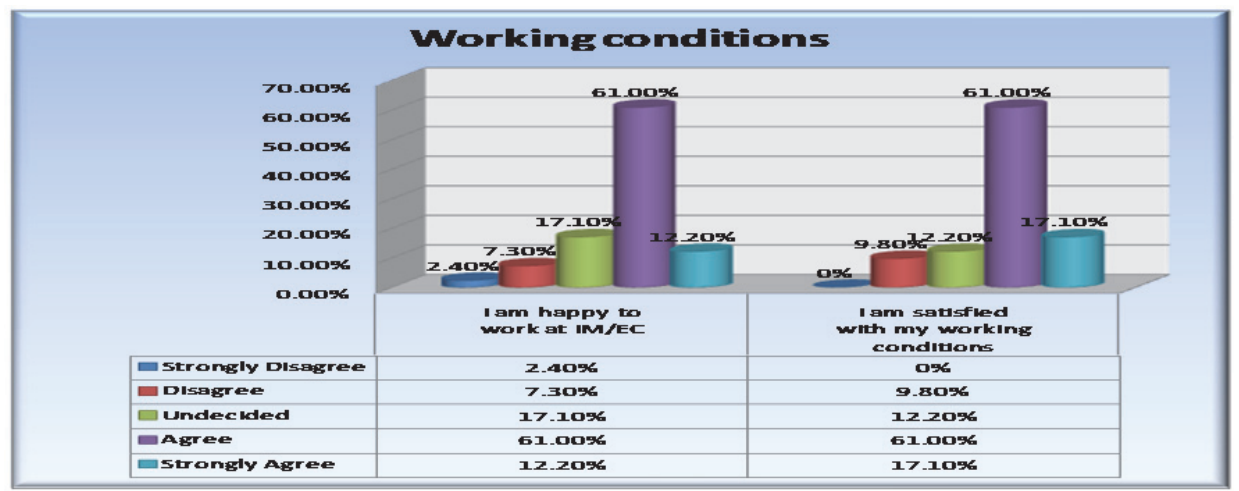

Figure 2: Working conditions

\subsubsection{Stimulating tasks}

In order to evaluate employees' perception of stimulating tasks as a job satisfaction factor, the following statements were provided. The first statement was: "I get the feeling of achievement from doing my job". The majority of employees agreed $(56.10 \%)$ and strongly agreed $(12.20 \%)$ with this statement. "My job is personally satisfying" was the second statement in this set. The responses to this statement were also positive, with 51 percent of the employees who agreed and 17.10 percent who strongly agreed with this statement. The last statement in this set - "My job is challenging" - also received fairly positive feedback, with 51.20 percent of the employees indicating that they agreed and 19.50 percent indicating that they strongly agreed. However, it must be noted that 14.6 percent of the employees did not agree with this statement. Figure 3 reflects the responses to the questions relating to stimulating tasks.

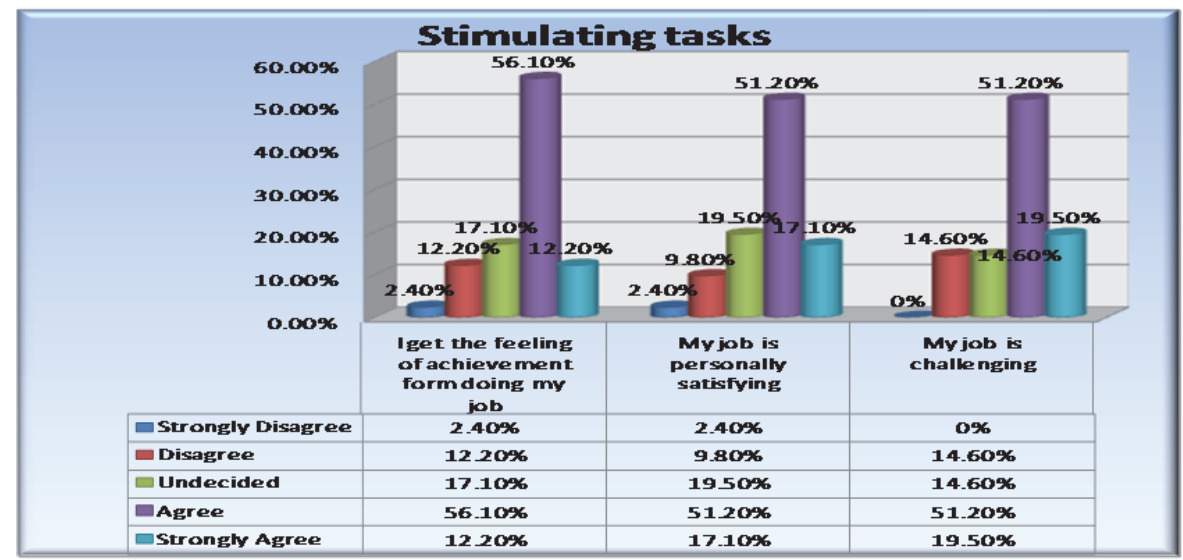

Figure 3: Stimulating tasks

\subsubsection{Responsibility and accountability for results}

In Figure 4 satisfaction with responsibility and accountability was evaluated. From the results, it is evident that most of the respondents indicated that they felt that they do have the opportunity to work independently. Although the majority also indicated that they felt that their work is clearly defined, 12.2 percent disagreed with this statement. The disagreement to this statement may be because some of the jobs are very closely related and are also, to a large degree, very dependent on each other. This might imply that some jobs overlap in certain areas, resulting in the perception that the work is not clearly defined. 


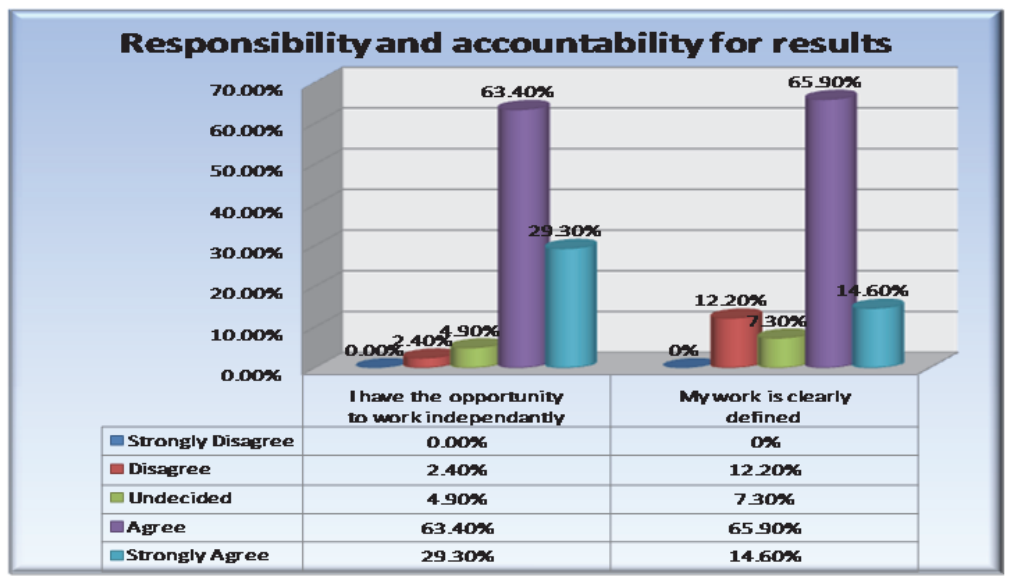

Figure 4: Responsibility and accountability for results

\subsubsection{Opportunities for learning and growth}

Employees' level of satisfaction (Figure 5) regarding their opportunities for learning and growth, were evaluated using two statements. The first statement related to the opportunity to gain personal growth and development from doing their job, while the second statement relates to the opportunity for further training and studies. Most of the respondents (agreed = $48 \%$; strongly agreed $=12 \%$ ) indicated that they felt that they had the opportunity for further training and studies. The responses to the statement regarding the opportunity to gain personal growth and development from doing their job indicated that the respondents were less satisfied 17.1 percent of the respondents having indicated that they disagreed with the statement. This may be because some of the jobs contain very 'routine' work that does not allow many opportunities for new learning experiences.

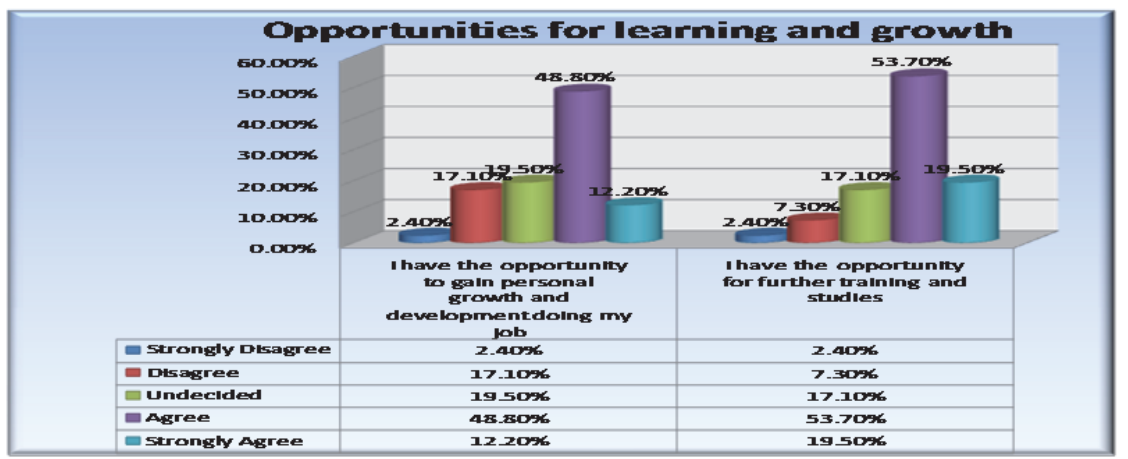

Figure 5: Opportunities for learning and growth

\subsubsection{Promotion opportunities}

The respondents' level of satisfaction regarding promotion opportunities is illustrated in Figure 6 . Although more than 50 percent agreed and strongly agreed that they were able to advance in their current jobs, 9.80 percent strongly disagreed and 14.60 percent disagreed with this statement. A possible reason for this is that only a certain amount of positions on certain levels are available. These positions only become available once the current incumbent leaves that position. 


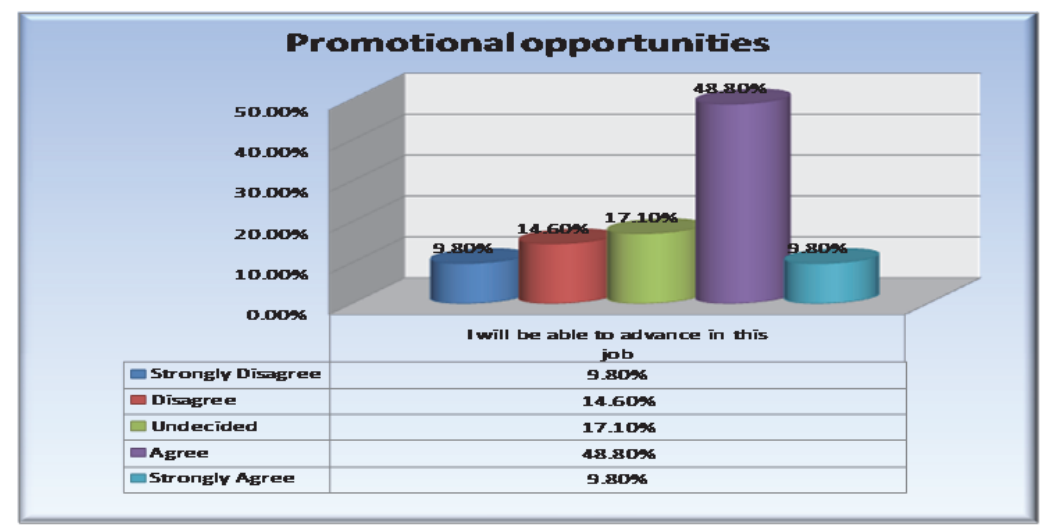

Figure 6: Opportunities for promotion

\subsubsection{Compensation/pay}

It is evident from Figure 7 that more than half $(56.1 \%)$ of the respondents, felt that they were fairly paid for the work that they were doing. However, less than 50 percent of the respondents felt that they were rewarded when certain milestones are achieved.

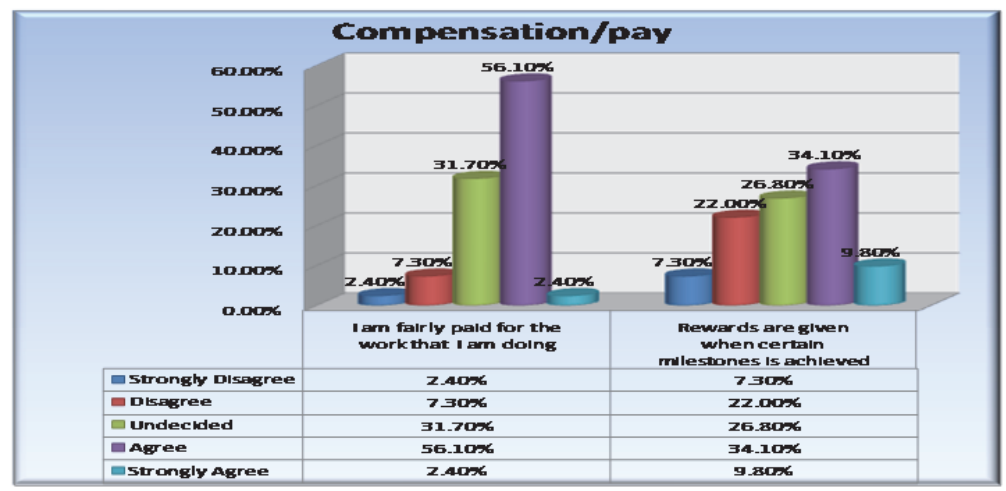

Figure 7: Compensation/pay

\subsubsection{Recognition}

As is apparent from Figure 8, the 'undecided' group of responses regarding recognition is large. Thirty nine percent of respondents agreed and 7.3 percent strongly agreed that informal praise was given frequently. The responses also indicate that 41.5 percent of the respondents agreed and 9.8 percent strongly agreed that they received recognition for their work. However, Figure 8 also illustrates that a significant amount of the respondents $(29.30 \%)$ felt that informal praise was not given frequently and 19.50 percent of the respondents stated that they did not get recognition for their work. 


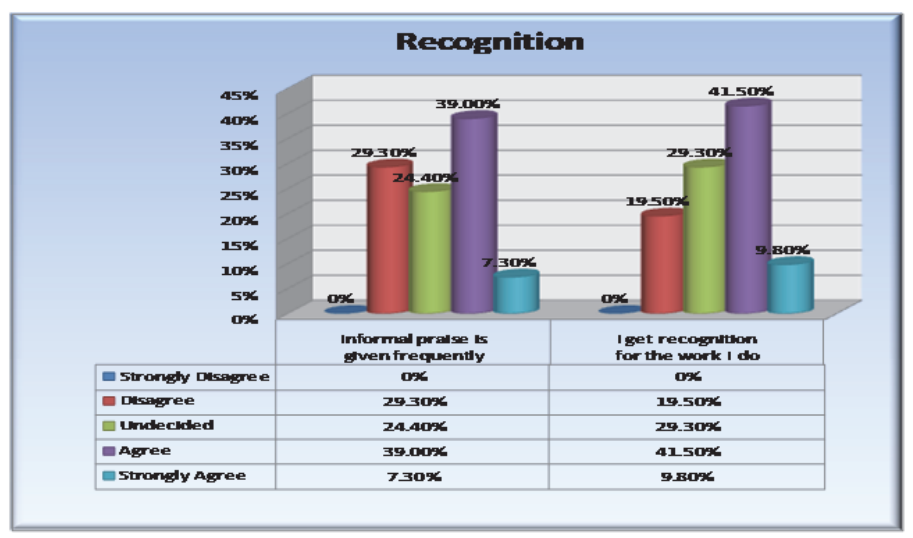

Figure 8: Recognition

\subsubsection{Co-workers}

More than 85 percent (Figure 9) of the respondents experienced their colleagues as being supportive. This indicates a high level of satisfaction with their co-workers.

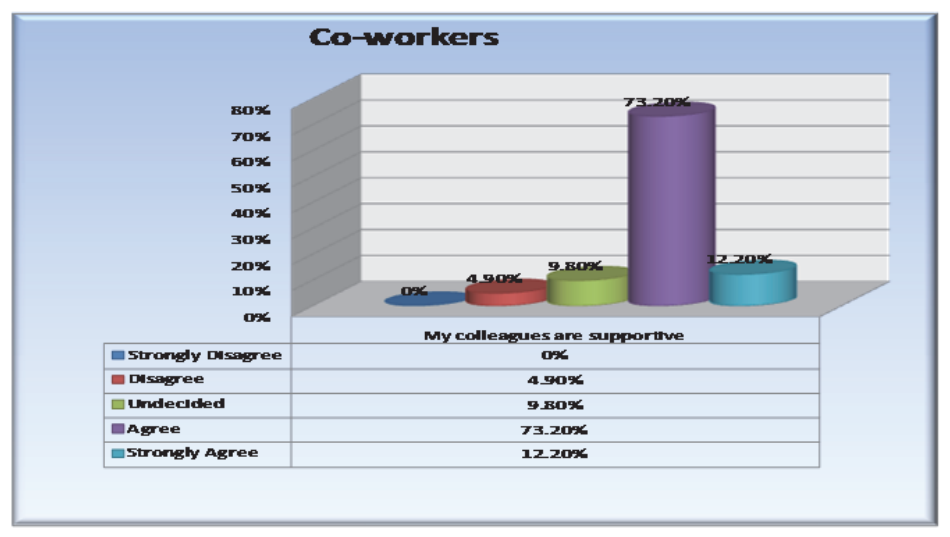

Figure 9: Co-workers

\subsubsection{Communication}

In order to evaluate how communication is perceived as a job satisfaction factor by the respondents, respondents were requested to evaluate four statements. The results are illustrated in Figure 10. It is evident that the respondents felt that their colleagues and managers were willing to share information. It is also evident that employee feedback is encouraged. An area of concern, however, is that less than 50 percent of the respondents perceived that the level of communication is effective. 


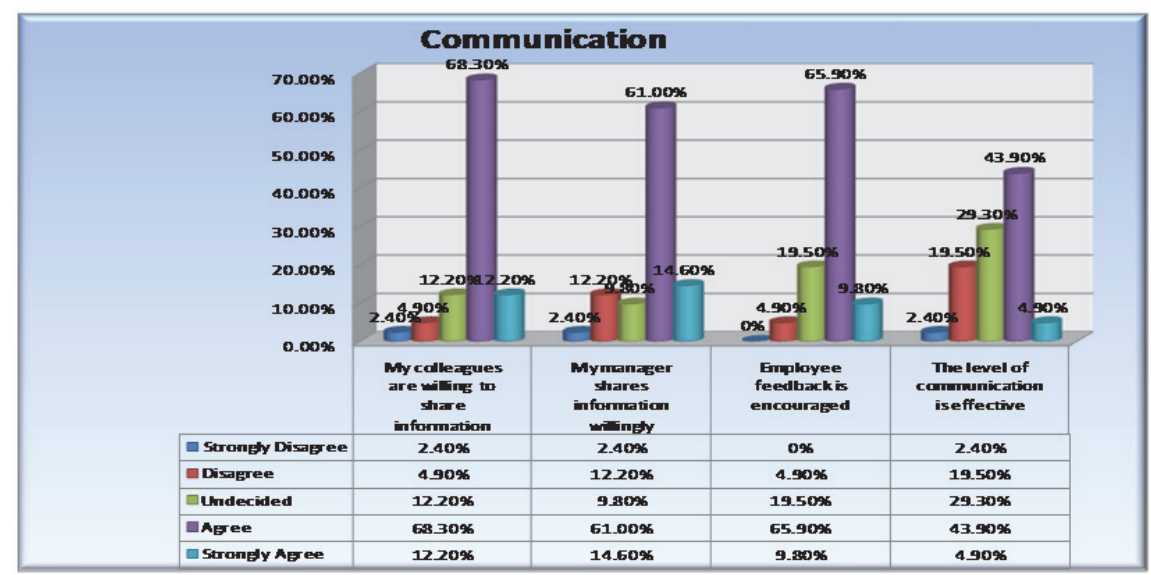

Figure 10: Communication

\subsubsection{Supervision/leadership}

In order to assess how employees perceived supervision and leadership as a job satisfaction factor, they were requested to respond to three statements. The first statement related to the respondents' satisfaction with the leadership style in the organisation. Less than 45 percent of the respondents indicated that they were satisfied with the leadership style. The second statement asked the respondents to indicate if they received the necessary support from their managers. More than 50 percent of the respondents agreed with this statement, with 36.60 percent being undecided. The final statement related to whether their manager involved them in important decisions. Although approximately 50 percent of the respondents replied positively to this statement, 9.80 percent strongly disagreed and 14.60 percent disagreed with this statement. The results of supervision and leadership are illustrated in Figure 11.

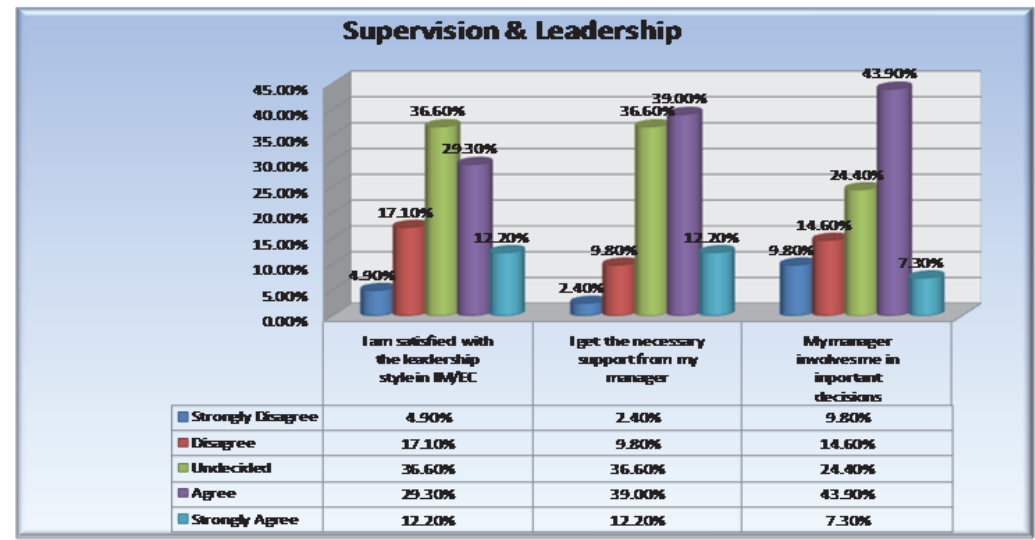

Figure 11: Supervision and leadership

\subsubsection{Job security}

Figure 12 illustrates the respondents' perception of job security. Of the respondents, 36.6 percent disagreed and 7.3 percent strongly disagreed with the statement that they feel uncertain about the future of their jobs. More than 45 percent of the respondents also indicated that they did not fear that they might lose their jobs. Although a large number of the respondents appeared to feel certain about the future of their jobs and feel that they might be able to remain working 
within the department, there were a number of respondents that felt uncertain about the future. Of the respondents, 22 percent agreed and 12.20 percent strongly agreed that they felt uncertain about the future of their jobs. This uncertainty was also observed through the 14.60 percent of respondents who agreed and 9.80 percent who strongly agreed that they feared that they might lose their job. One reason for this uncertainty could be the fact that the organisation was at the time of the study considering centralising all the services, including those in the IM environment. A second reason could be the worldwide economic downfall being experienced, which had a large impact on the chemical industry in South Africa.

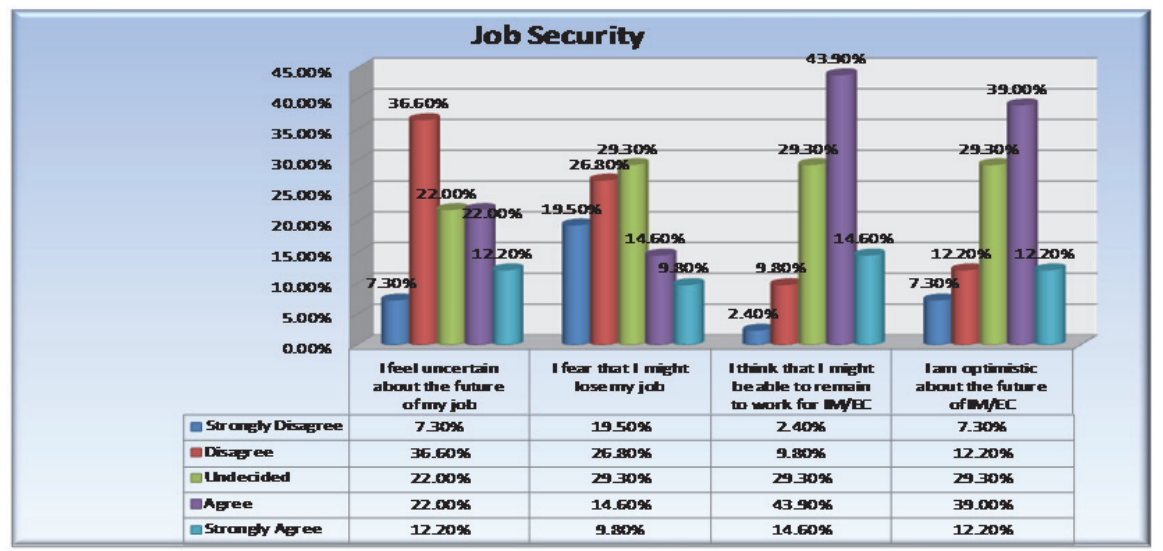

Figure 12: Job security

\subsection{Job Satisfaction Factors}

The importance of the job satisfaction factors which were identified through the literature study were established. In order to display the results, the findings are grouped into two sets of figures, each containing three figures. The first set illustrates the job satisfaction factors that were identified as 'very important' to the respondents, while the 'important' job satisfaction factors are illustrated by the second set.

The five most important job satisfaction factors for the total ICT department, in order of importance, were communication, good working conditions, job security, opportunities for learning and growth, and recognition.

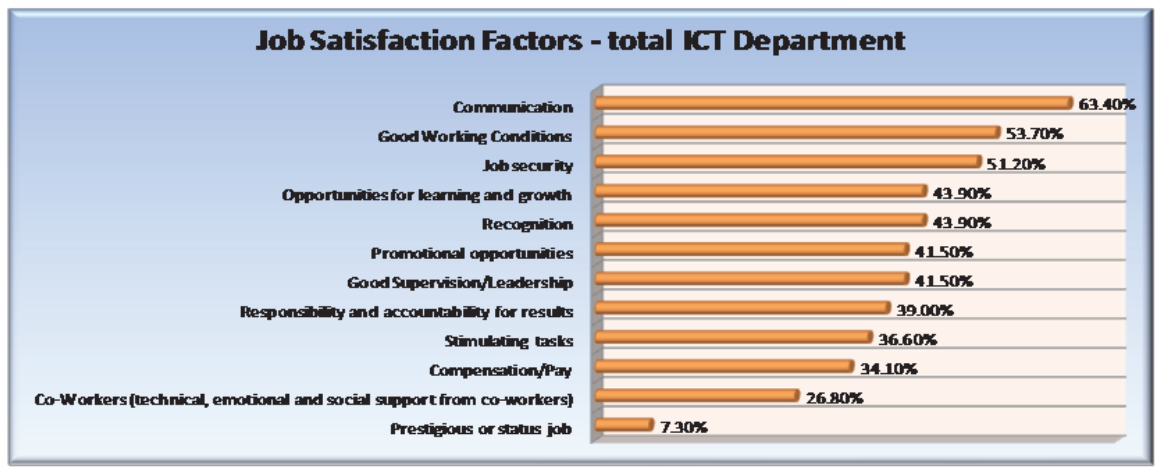

Figure 13: Job satisfaction factors - total ICT department

The most important job satisfaction factors according to each department (IM and EC) are illustrated in Figure 13 and Figure 14, respectively. According to Figure 4.19, the most important job satisfaction factors for the IM department were communication, opportunities for learning and growth, stimulating tasks, good working conditions, promotional 
opportunities and recognition.

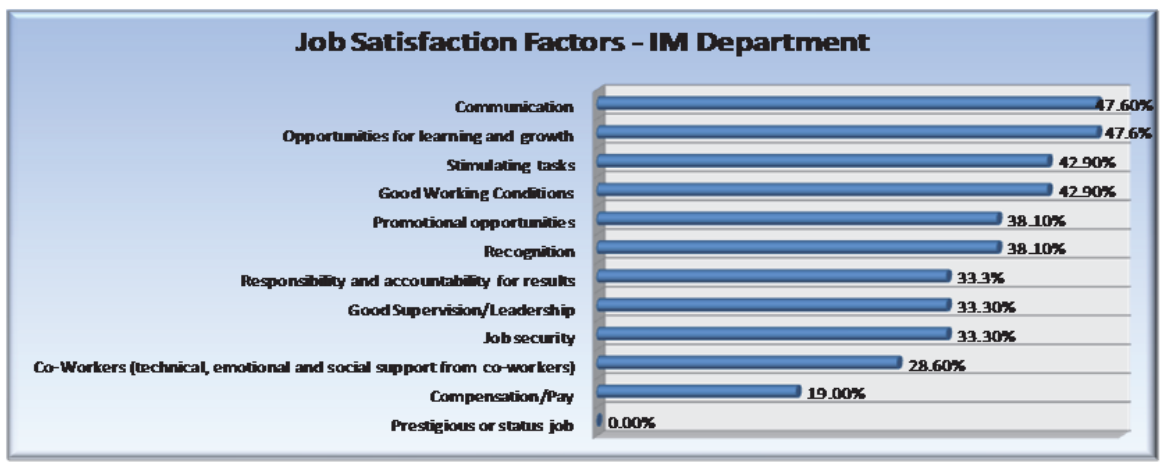

Figure 14: Job satisfaction factors - IM department

The most important job satisfaction factors (Figure 15) for the EC department were communication, good working conditions, job security, good supervision/leadership, recognition and compensation/pay. It is evident that communication is seen as the most important job satisfaction factor by both departments.

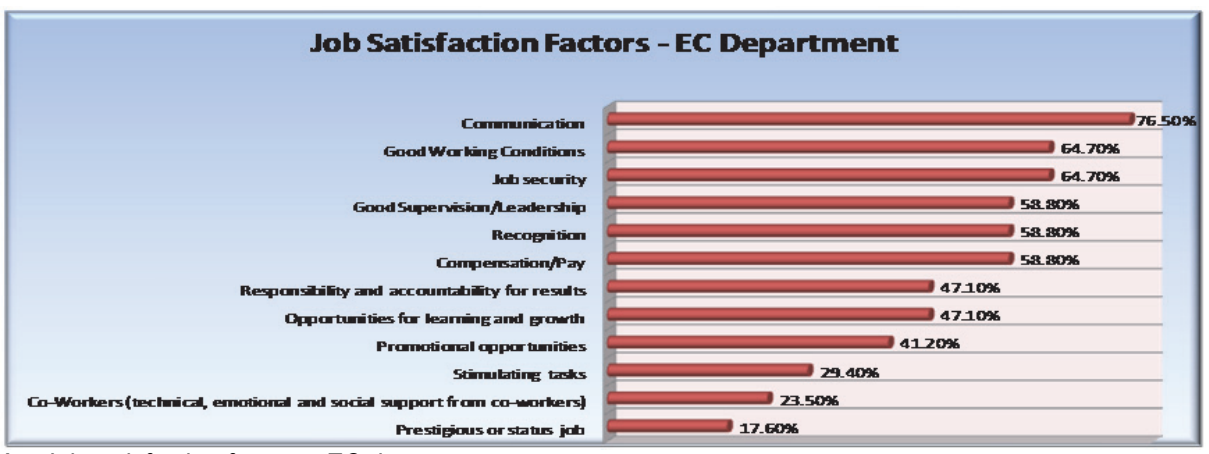

Figure 15: Job satisfaction factors - EC department

The following set of figures illustrates what job satisfying factors were important to the respondents. Figure 16 shows the important job satisfying factors for the total ICT department. Co-workers (that is technical, emotional and social support) is seen as the most important job satisfaction factor as per the total ICT department. This is followed by stimulating tasks, compensation/pay, promotional opportunities and responsibility and accountability for results.

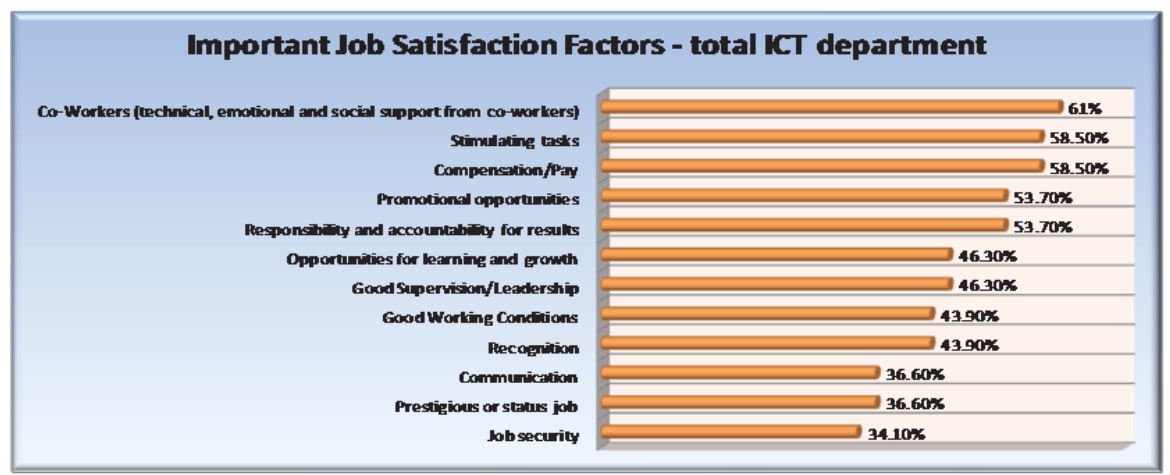

Figure 16: Important job satisfaction factors - total ICT department

$$
\sim 506 \sim
$$


The classification of the most important job satisfaction factors per ICT department was as follows:

Information management: compensation/pay, stimulating tasks, promotional opportunities, responsibility and accountability for results, and co-workers.

Electronics and communication: stimulating tasks, co-workers, responsibility and accountability for results, and promotional opportunities.

On the whole, it is apparent from the results that both the sub-departments experienced similar job satisfaction factors as important. The important job satisfaction factors per sub-department are illustrated in Figures 17 and 18, respectively.

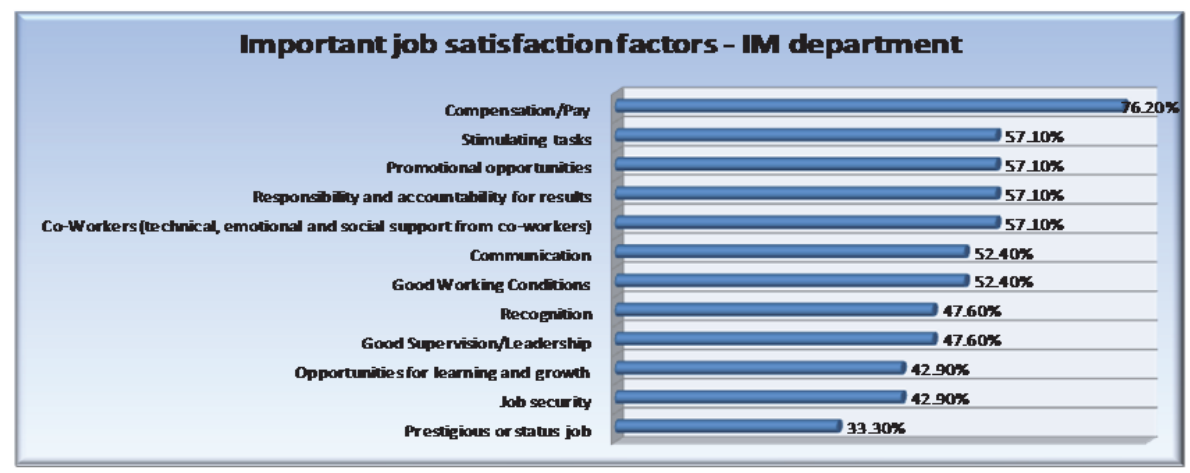

Figure 17: Important job satisfaction factors - IM department

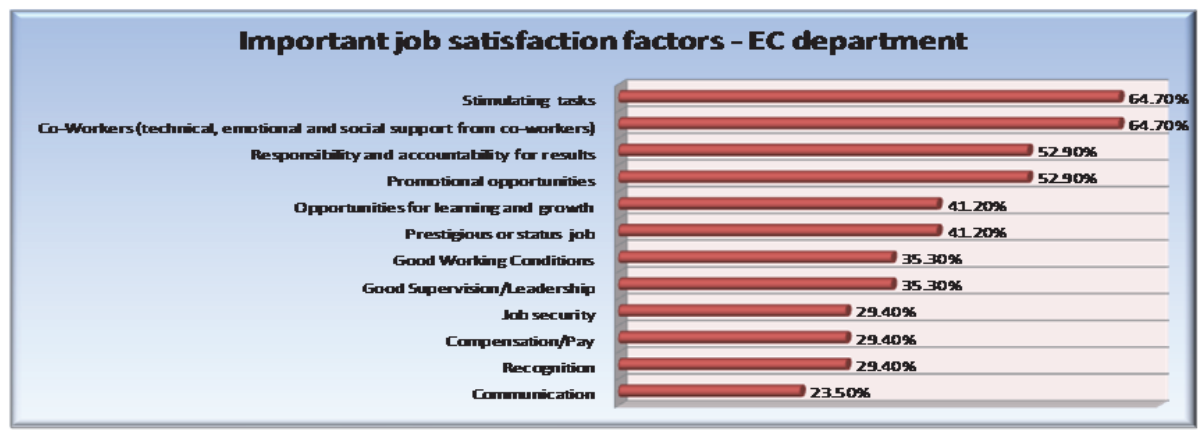

Figure 18: Important job satisfaction factors - EC department

\section{Conclusion}

In today's competitive business world organisations are exposed to a number of challenges. One of the most significant issues organisations are facing is the retention of talented employees. It is apparent that job satisfaction, motivation and the creation of an attractive working environment plays an important role in employee retention. It is therefore essential for organisations to understand what influences a person's choice to stay in a position or to move on. From the research it is evident that motivation, staff retention and job satisfaction do not exist in isolation but are closely related. Employees are not motivated by a single motivational factor and are not satisfied with their jobs simply by experiencing satisfaction with only one aspect of their job. Rather, job satisfaction and motivation is the result of a combination of several different elements. The findings of this research may improve organisations' awareness of the facilitation of work environments with regards to motivation, job satisfaction and staff retention. The challenge is to find the optimum combination of these elements in order to ensure satisfied employees. Having achieved this, organisations will be able to retain their most valued employees. 


\section{References}

Akinyele, S.T. \&Olorunleke, K. (2010). Technology and service quality in the banking industry: An empirical study of various factors in electronic banking services. International Business Management, 4, 209-221.

Aldalaigan, A.H. \&Buttle, F.A. (2002). SYSTRA-SQ: A new measure of bank service quality. Industrial Journal of Service Industry Management, 13(3), 362-381.

Al-Hawari, M. \& Ward, T. (2006).The effect of automated service quality on Australian banks' financial performance and the mediating role of customer satisfaction. Marketing Intelligence \& Planning, 24(2), 127-147.

Amos, T., Ristow, A. \& Ristow, L. (2004). Human Resource Management. $2^{\text {nd }}$ ed. Lansdowne: Juta.

Arnold, H. J. \& Feldman, D.C. (1988). Organizational Behaviour. New York: McGraw-Hill Book

Company.

Chew, J. \& Chan, C.C.A. (2008). Human resource practices, organisational commitment and intention to stay. International Journal of Manpower, 29(6), 503-522. Retrieved from http://www.emeraldinsight.com

Clark, R.M. (2009). Are we having fun yet? Creating a motivating work environment. Industrial and Commercial Training, 41(1), 43-46. Retrieved from http://www.emeraldinsight.com

De Vos, A. \& Meganck, A. (2009). What HR managers do versus what employees value: Exploring both parties' view on retention management from a psychological contract perspective. Personnel Review, 38(1), 45-60. Retrieved from http://www.emeraldinsight.com

De Vos, A.S., Strydom, H., Fouche, C.B. \& Delport, C.S.L. (2005). Research at Grass roots: for the social sciences and human service professions. $3^{\text {rd }}$ ed. Pretoria: Van Schaik.

Fox, W. (2006). Managing Organisational Behaviour. 1st ed. Cape Town: Juta.

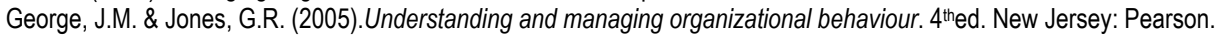

Glen, C. (2006). Key skills retention and motivation: the war for talent still rages and retention is the high ground. Industrial and Commercial Training, 38(1), 37-45. Retrieved from http://www.emeraldinsight.com

Gostick, A. \& Elton, C. (2007).The carrot principle: how the best managers use recognition to engage their people, retain talent, and accelerate performance. 1 sted. New York: Free Press.

Huang, I., Lin, H. \& Chuang, C. (2006). Constructing factors related to worker retention. International Journal of Manpower, 27(5), 491508. Retrieved from http://www.emeraldinsight.com

Kaye, B. \& Jordan-Evans, S. (2005). Love 'em or Lose 'em: Getting good people to stay. 1 st ed. San Francisco: Berrett-Koehler.

Luna-Arocas, R. \& Camps, J. (2008). A model of high performance work practices and turnover intentions. Personnel Review, 37(1), 2646. Retrieved from http://www.emeraldinsight.com

Maurer, T.J. \&Lippstreu, M. (2008). Who will be committed to an organisation that provides support for employee development. Journal of Management Development,27(3), 328-347. Retrieved from http://www.emeraldinsight.com

Mayfield, J. \& Mayfield, M. (2008). The creative environment's influence on intent to turnover: A structural equation model and analysis. Management Research News, 31(1), 41-56. Retrieved from http://www.emeraldinsight.com

Nelson, D.L. \& Quick, J.C. (2006). Organizational Behaviour: Foundations, Realities \& Challenges. $5^{\text {th }}$ ed. Ohio: Thomson.

O' Malley, M. (2000).Creating commitment: How to attract and retain talented employees by building relationships that last. $1^{\text {st }}$ ed. USA: Wiley.

Park, S.P. \& Kim, T.H. (2009). Do types of organisational culture matter in nurse job satisfaction and turnover intention? Leadership in Health Services,22(1), 20-38. Retrieved from http://www.emeraldinsight.com

Robbins, S.P., Odendaal, A. \& Roodt, G. (2004).Organisational Behaviour: Global and Southern African Perspectives. $5^{\text {th }}$ ed. Cape Town: Pearson.

Taylor, L.J., Murphy, B. \& Price, W. (2006). Goldratt's thinking process applied to employee retention. Business Process Management Journal, 12(5), 646-670. Retrieved from http://www.emeraldinsight.com

Van Dam, K. (2008). Time frames for leaving. An explorative study of employees' intentions to leave the organisation in the future. Career Development International,13(6), 560-571. Retrieved from http://www.emeraldinsight.com

Welman, C., Kruger, F. \& Mitchell, B. (2005).Research Methodology. $3^{\text {rd }}$ ed. Cape Town: Oxford. 